\title{
Consensus
}

Volume 29

Issue 2 Leavening the Lump

Article 19

$11-11-2004$

\section{Christianity with an Asian face: Asian American theology in the making}

Oscar Cole-Arnal

Follow this and additional works at: http://scholars.wlu.ca/consensus

\section{Recommended Citation}

Cole-Arnal, Oscar (2004) "Christianity with an Asian face: Asian American theology in the making," Consensus: Vol. 29 : Iss. 2 , Article 19.

Available at: http://scholars.wlu.ca/consensus/vol29/iss2/19

This Book Reviews is brought to you for free and open access by Scholars Commons @ Laurier. It has been accepted for inclusion in Consensus by an authorized editor of Scholars Commons @ Laurier. For more information, please contact scholarscommons@wlu.ca. 
traditions with newer expressions of faith. The Emerging Church movement in the U.S. and the alternative worship movement in the UK are excellent examples of churches engaging the postmodern culture with integrity to what the Western Tradition has passed down, but also effective in reaching the "de-churched." These "postmodern" churches use the creative arts, technology, and community building to bring the message of the gospel to the "post-Christian" western world. This book completely ignored this creative and energetic movement.

All this being said, this volume offers serious theological reflection on the "whys" and "hows" of re-evangelization within our churches while remaining faithful to our liturgical and theological traditions. While this book doesn't represent the many sides of the debate, it does provide an excellent overview of one side.

Kevin Powell

Lutheran Church of the Resurrection

Halifax, Nova Scotia

\section{Christianity with an Asian Face:}

Asian American Theology in the Making

Peter C. Phan

Maryknoll, New York: Orbis Books, 2003

253 pages, \$34.97 Softcover

The fact that Lutheranism in Canada has experienced a notable increase of Asians within its ranks serves as sufficient logic for more serious examination of Asian contributions to our denomination's theological project. Beyond that lies a reason which perhaps is greater: Asian Christian thinkers have creativity and insights to offer to our more narrow Eurocentric focus. Morevoer, tapping into such resources underscores the full inclusion of the gospel which dare not become imprisoned to one cultural model for its theological discourse.

As Waterloo Lutheran Seminary's church historian I feel compelled and called to mine this theological mother lode in order to
Published by Scholars Commons @ Laurier, 2004 
assist me in working with a recent influx of Asian students in our seminary courses. Christianity with an Asian Face, by Vietnamese Catholic scholar Peter Phan, emerges as one example of the numerous studies from Asian sources which have appeared in the last twenty years, most of them from the Orbis Book firm created by the Maryknoll Fathers.

Phan's work provides a judicious blend of traditional social Catholic models infused and re-invigorated with avant-garde Asian insights peppered with liberation theology's own unique contributions. To be sure, Canadian Lutherans need to translate these insights from American to Canadian, from Vietnamese to Chinese, and from Catholic to Protestant, but such challenges do not detract from the value of the material found in Phan's experiences and reflections. For example, when he deals with the immigration of Asians to the United States with that painful split of belonging neither to the old culture or the new, he mirrors the difficulty of Chinese Lutheran members in Toronto and Vancouver as well.

The first sections of the book include methodological pieces that assist in shaping a theology of enculturation designed to assist Asian immigrant Christians in their adaptation to a new sociological space while continuing to feed from the riches of the traditions that they bring to their new home. Phan shows himself adept as both a supporter and critic of papal documents on cultural theology while, at the same time, he integrates the early liberationist hermeneutics within a broader multi-cultural mode. At the book's end he seeks to portray very specific forms and structures of Asian theology within his own church context, including solid analysis of catechetical practices among Asian Christians.

However, what I most appreciated about the book involved those middle sections dealing with theological concepts adapted to the Asian environment. These chapters included critically supportive descriptions of some key Asian thinkers and groups currently active in this process such as Korean minjing liberationism. Phan provides a sophisticated and compelling analysis of the means by which Asian loyalty to the historicity of the Biblical and early church traditions includes the incorporation of the Asian historical experience. He shows how this is accomplished in a way that avoids both abstractions and slavish identification with the historical and western grounding of the Christian faith. Powerful religious forces in the 
Asian experience, like ancient philosophical values and "ancestor worship," are sensitively handled so as to allow Asian Christians to translate these venerable traditions into culturally relevant christologies. Although I am not prepared to suggest Phan's Christianity with an Asian Face as a "must read" on Asian Christianity, it remains an exciting and insightful work in the genre.

Oscar Cole-Arnal

Waterloo Lutheran Seminary

Waterloo, Ontario

\section{The Moral Vision of Cesar Chávez}

Frederick John Dalton

Maryknoll, New York: Orbis Books, 2003

200 pages, $\$ 23.07$ Softcover

In the years when protest filled the American landscape, and martyrs like the Kennedy brothers and Martin Luther King, Jr., filled the front pages, the saintly figure of Cesar Chávez and his United Farm Workers Movement (UFW) received comparatively little attention. In spite of this lack of national mass media coverage, often reserved for the Vietnam War and its fallout, the Chicano labour movement, inspired and led by the diminutive hero of Delano, California, made history and produced one of the few genuine American saints. Dalton's fine work describes and analyses these realities in a way that is both thoughtful and inspirational.

After acknowledging the personal impact Cesar Chávez had on his life, the author sets for himself the task of defining La Causa's leader from the standpoint of his "moral vision." Such a goal faces the serious pitfall of being obsessed with concepts to the detriment of context, the particular sin of white, western and comfortable ethicists. Dalton does not fall into this trap. To be sure, his careful prose avoids the rhetoric of an impassioned partisan, but he takes great pains to present a "flesh and blood" union and its charismatic leader. We encounter the privation and hardship of the Chicano field hands and their families through Chávez', own background. We see the familial
pubished by scholars Commons 